\title{
A Dilution Method for the Assay of Streptomycin
}

\author{
By ANNIE M. BROWN and P. A. YOUNG \\ The Wellcome Physiological Research Laboratories, Beckenham, Kent
}

\begin{abstract}
SUMMARY: A dilution method for the assay of streptomycin is described using a digest nutrient broth as the test medium and a certain strain of Escherichia coli (Bacterium coli) as the test organism. The inhibition end-point is estimated turbidimetrically by comparison with that in a standard solution of streptomycin base. The accuracy of the method when employed as described is of the order of $\pm 15 \%$. It is necessary to control the dilution of the test medium, the temperature of incubation of the tests, the size of the inoculum and hydrogen-ion concentration in order to obtain consistent results. With dilution of the medium the sensitivity of the test is increased while its accuracy is decreased. The use of an inoculum of constant size is important, and an incubation temperature of $28^{\circ}$ is found to be more satisfactory than $37^{\circ}$. Medium with a hydrogen-ion concentration of $\mathrm{pH} 7 \cdot 6$ affords greater sensitivity than that with a lower $\mathrm{pH}$ value.
\end{abstract}

During studies of streptomycin production by Streptomyces griseus (see Ainsworth, Brown, Marsden, Smith \& Spilsbury, 1947; Woodthorpe \& Ireland, 1947 ) it was necessary to assay the activity of the culture fluids. Several methods for streptomycin assay are noted by Waksman \& Schatz (1945), but a dilution test similar to that described by Pope \& Stevens (1946) for penicillin was favoured for routine use. The method finally adopted, which gives little trouble providing constant conditions are maintained, is described below.

The unit of streptomycin. American workers have used the S unit of Waksman (1945) which was defined as that amount of material which will inhibit the growth of a standard strain of Escherichia coli (Bacterium coli) in $1 \mathrm{ml}$. of nutrient broth or other suitable medium. This corresponds to the original $E s c h$. coli unit and was said to be equivalent to $1 \mu \mathrm{g}$. of crystalline streptomycin. It has, however, since been stated that pure streptomycin base contains approximately 800 units/mg. (Molitor, Graessle, Kuna, Mushett \& Silber, 1946). For this reason it is considered less ambiguous to express activities as $\mu \mathrm{g}$. of streptomycin base $/ \mathrm{ml}$. or $/ \mathrm{mg}$. and so avoid the use of unstandardized units.

The standard used. Three samples of streptomycin sulphate were received from America, two from Merck and Co. Inc., and one from Chas Pfizer and Co. Inc., the former labelled with the weight of streptomycin base/phial, and the latter with its purity specified. It was deduced from the weight of material in the phials received that the first two samples each contained $500 \mu \mathrm{g}$. of streptomycin base/mg. This agreed, within the limits of error of the test, with the stated streptomycin content of the third sample. An independent spectrographic method of assay developed by Dr Tudor Jones of the Wellcome Chemical Research Laboratories (unpublished), gave essentially the same titres for the three American samples as did the biological assay. The Merck sample was considered as standard for pharmacological reasons (Madigan, Swift \& Brownlee, 1947). 
Test organism. The organism used for this test was Esch. coli strain CN 636, available in the dried state at the Wellcome Physiological Research Laboratories, Beckenham. This organism is easy to control and its non-pathogenicity is in its favour.

Test medium. The influence of various substances such as glucose, thiol compounds and ketone reagents, and of hydrogen-ion concentration on the activity of streptomycin has been noted by a number of workers (Denkelwater, Cook \& Tishler, 1945; Geiger, Green \& Waksman, 1946; Donovick \& Rake, 1946; Abraham \& Duthie, 1946; Bondi, Dietz \& Spaulding, 1946; Wolinsky \& Steenken, 1946; Van Dolah \& Christenson, 1947). In experiments described below the action of certain of these compounds could be correlated with the effect on hydrogen-ion concentration, but for others, particularly thiol compounds and ketone reagents, the nature of the effect was obscure. The sensitivity to these compounds and to the concentration of peptone used, as described by Donovick \& Rake (1946), made a control of the test medium very necessary (cf. Hobby, Lenert \& Hyman, 1946). A nutrient broth which could readily be produced in large batches by the method detailed below was found to be very suitable.

\section{DETAILS OF THE ASSAY METHOD}

Preparation of the nutrient broth. Minced horseflesh $(20 \mathrm{lb}$.) was mixed with tap water $\left(9 \mathrm{l}\right.$.) and heated to $60^{\circ}$. The $\mathrm{pH}$ was then adjusted to $5 \cdot \mathbf{2}-\mathbf{5} \cdot 6$ with $\mathrm{HCl}$ and $30 \mathrm{~g}$. of papain was added in $10 \mathrm{~g}$. quantities hourly. During digestion the temperature was kept between 58 and $62^{\circ}$. After $4 \mathrm{hr}$. the $\mathrm{pH}$ was adjusted to $5 \cdot 0-5 \cdot 5$ with $\mathrm{HCl}$ and the product boiled and filtered. The filtrate was reheated to $90^{\circ}$ and then allowed to stand overnight, after which it was filtered and stored.

A sufficient quantity of this papain digest was diluted with tap water togive a total $\mathrm{N}$ content of $\mathbf{1} \cdot 6 \mathrm{~g} . / \mathrm{l}$. Sodium chloride was added to give a final concentration of $0.5 \%$, allowance being made for that already present in the medium. A mixture was then made containing the proportions $1 \mathrm{l}$. of this diluted digest and $1 \mathrm{lb}$. of minced horse muscle. This mixture was heated to $65^{\circ}$, maintained at that temperature for $20 \mathrm{~min}$., then boiled for $30 \mathrm{~min}$. The meat particles were allowed to settle and the supernatant liquid decanted. Liquor remaining in the meat was squeezed out in a press, and the whole volume of liquor was collected and made up with distilled water to the original volume of papain digest used. The broth was adjusted to $\mathrm{pH} 7 \cdot 6$ with $\mathrm{NaOH}$, boiled, and filtered through paper or cloth precoated with Hyflo Supercel (Johns Manville Ltd.) according to the size of the batch.

When preparing medium for the assay several bottles of nutrient broth prepared as above were bulked and the $\mathrm{pH}$ checked. The medium was then distributed in volumes of $5 \cdot 0 \mathrm{ml}$. by an automatic measurer into $4 \times 1 \mathrm{in}$. tubes. These were autoclaved for $10 \mathrm{~min}$. at $10 \mathrm{lb}$./sq.in., a procedure which did not affect the volume. The $\mathrm{pH}$ of the broth after autoclaving was also noted, as any variation of more than $0 \cdot 1 \mathrm{pH}$ unit had an appreciable effect on the end-point dilution of the streptomycin standard. 
Maintenance of culture and preparation of inoculum. The Esch. coli strain was maintained on nutrient agar slopes. In order to diminish the frequency of subculture, each week six slopes were inoculated from the parent slope and after $24 \mathrm{hr}$. growth at $37^{\circ}$ were stored in a cold room. Each day of the week following subcultures into nutrient broth were made from one of these slopes, incubated for $17 \mathrm{hr}$. and held at $4^{\circ}$ until required for use. A satisfactory inoculum was obtained by using 0.2 or $0.3 \mathrm{ml}$. of a $10^{-6}$ dilution of such a $17 \mathrm{hr}$. culture. Inoculation by means of a wire was unsatisfactory because the organism is very sensitive to heat and inoculation tended to be patchy.

Preparation of standard streptomycin solution. A sufficient volume of a solution of the standard streptomycin sulphate containing $200 \mu \mathrm{g} . / \mathrm{ml}$. was dispensed in phosphate buffer $\left(0 \cdot 1 \% \mathrm{Na}_{2} \mathrm{HPO}_{4}\right.$ adjusted to $\mathrm{pH} 7$ with phosphoric acid) to last at least a week. No deterioration of this solution has been detected when stored in the cold room. Before addition to the series of tubes for assay this solution was diluted 10 or 15 times with nutrient broth. A small amount of chloroform was added to the original phosphate buffer to preserve sterility, and all other dilutions were made with sterile precautions.

Determination of assay end-point. The weight of streptomycin base producing inhibition in growth of Esch. coli was determined in the following manner. Standard streptomycin solution was added to a series of $5 \mathrm{ml}$. amounts of broth in the following volumes $(\mathrm{ml}):. 1 \cdot 4,1 \cdot 3,1 \cdot 2,1 \cdot 1,1 \cdot 0,0 \cdot 9,0 \cdot 8,0 \cdot 7,0 \cdot 65$, giving a ' $10 \%$ range' with a dilution factor of 1.07-1.12. Each tube was inoculated with $0.3 \mathrm{ml}$. of a $10^{-6}$ dilution of $17 \mathrm{hr}$. culture of Esch. coli in nutrient broth, shaken vigorously, and incubated for about $16 \mathrm{hr}$. at $28^{\circ}$. The tube in which only a trace of growth appeared was taken as the end-point.

As a general rule there was rapid transition from no growth to positive growth, and the end-point tube was not difficult to locate. The amount of streptomycin present in the end-point tube was then calculated. For example, when this tube contained $0.9 \mathrm{ml}$. of the $1 / 10$ dilution of the standard $200 \mu \mathrm{g} . / \mathrm{ml}$. streptomycin solution, the total volume being $6.2 \mathrm{ml}$. $(5.0 \mathrm{ml}$. broth $+0.9 \mathrm{ml}$. streptomycin dilution $+\mathbf{0 \cdot 3} \mathrm{ml}$. inoculum), the amount of pure streptomycin base/ml. is given by

$$
\frac{200}{10} \times \frac{0 \cdot 9}{6 \cdot 2}=2 \cdot 90 \mu \mathrm{g} . \text { pure base } / \mathrm{ml} .
$$

This end-point varied slightly from day to day, and it was necessary therefore always to include two standard ranges among each day's tests.

\section{THE METHOD OF ASSAY}

Samples for assay were saturated with chloroform to inhibit the growth of any chance contamination. As the least possible dilution of a sample was $1 / 3.5$ and was usually much greater, there was no danger of inhibition of growth by the chloroform alone, a saturated solution of which does not inhibit growth at greater dilutions than $1 / 2$.

When testing samples of unknown value ranges covering volumes from $\mathbf{2} \cdot 0$ to 
$0.5 \mathrm{ml}$. of the sample at two levels of dilution were generally used, e.g. $5 \mathrm{ml}$. tubes of broth with the addition of:

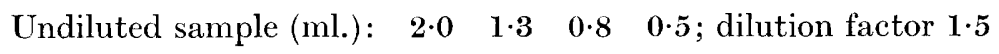

Sample diluted $1: 3(\mathrm{ml}):. 2 \cdot 0 \quad 1 \cdot 3 \quad 0 \cdot 8 \quad 0 \cdot 5$; dilution factor $1 \cdot 5$.

If considerable amounts of streptomycin were suspected larger dilutions of the sample were made. In all tests the final ranges were similar to those shown in the paper by Pope \& Stevens (1946), with dilution factors 1·20-1·10. All dilutions were made with sterile precautions in nutrient broth at $\mathrm{pH} 7 \cdot 6$. This was essential owing to the effect of the dilution of the medium on the activity of the streptomycin (see Donovick \& Rake, 1946; and below). The tests were inoculated in the same way as the standard dilutions and incubated for $16 \mathrm{hr}$. at $28^{\circ}$.

In order to facilitate calculation of the potency of samples, tables were calculated for all possible variations of the standard end-point. A small portion of one of these tables is shown in Table 1.

Table 1. Part of table giving the relation of dilution end-points of standard and sample

$\begin{array}{cc}\begin{array}{c}\text { End-point } \\ \text { of standard mycin base } \\ (20 \mu \mathrm{g} . / \mathrm{ml} .) \\ (\mathrm{ml}))\end{array} & \begin{array}{c}\text { Strepto- } \\ \text { equivalent } \\ (\mu \mathrm{g} .)\end{array} \\ & \\ & \\ 1 \cdot 1 & 3 \cdot 54 \\ 1 \cdot 0 & 3 \cdot 22 \\ 0.9 & 2 \cdot 90\end{array}$

Streptomycin base equivalents for dilutions of samples giving end-points at:
Volume of dilution added (ml.)
$\begin{array}{llllllllllll}2 \cdot 0 & 1.8 & 1.6 & 1.4 & 1.3 & 1.2 & 1.1 & 1.0 & 0.9 & 0.8 & 0.7 & 0.65\end{array}$
Equivalents of streptomycin base $(\mu \mathrm{g}$.

$\begin{array}{llllllllllll}12.5 & 13.5 & 14.5 & 16.0 & 17.0 & 18.5 & 19.5 & 21.0 & 23.0 & 25.5 & 29 \cdot 0 & 31.0\end{array}$

$\begin{array}{llllllllllll}11.5 & 12.0 & 13.5 & 14.5 & 15.5 & 16.5 & 18.0 & 19.5 & 21.0 & 23.5 & 26.0 & 28 \cdot 0\end{array}$

$\begin{array}{llllllllllll}10 \cdot 0 & 11.0 & 12.0 & 13 \cdot 0 & 14.0 & 15 \cdot 0 & 16 \cdot 0 & 17.5 & 19 \cdot 0 & 21 \cdot 0 & 23.5 & 25 \cdot 0\end{array}$

If the standard end-point was on $\mathbf{1 \cdot 0}$, and the sample dilution end-point on $\mathbf{1} \cdot \mathbf{4}$, then from the table the sample dilution contained $\mathbf{1 5 \cdot 0} \mu \mathrm{g}$. of streptomycin base $/ \mathrm{ml}$. This multiplied by the dilution of the sample gave its potency.

The accuracy of the potency determinations can be seen from Table 2. No special choice of workers was made when assaying these samples. From the standard deviation of a single test it is clear that the potency of a sample can be determined as described above to about $\pm 15 \%$, which is satisfactory for a routine assay of this nature.

Table 2. The accuracy of the streptomycin assay

\begin{tabular}{|c|c|c|c|c|}
\hline Series & No. tests & $\begin{array}{l}\text { Potency } \\
(\mu \mathrm{g} . / \mathrm{mI} .)\end{array}$ & $\begin{array}{l}\text { Standard } \\
\text { deviation of } \\
\text { single test }\end{array}$ & $\begin{array}{c}\text { Coefficient } \\
\text { of variation } \\
(\%)\end{array}$ \\
\hline A & 11 & 172 & $\pm 36 \cdot 7$ & $\pm 21 \cdot 3$ \\
\hline B & 12 & $318 \cdot 8$ & $\pm 46 \cdot 4$ & \pm 14.5 \\
\hline C & 19 & $293 \cdot 5$ & \pm 41.5 & \pm 14.2 \\
\hline D & 16 & $167 \cdot 5$ & $\pm 19 \cdot 2$ & \pm 11.5 \\
\hline $\mathrm{E}$ & 20 & $156 \cdot 3$ & $\pm 13 \cdot 4$ & $\pm 8 \cdot 6$ \\
\hline
\end{tabular}




\section{Comments on the assay method}

Concentration of broth. It was found that dilution of the test medium resulted in a higher relative activity of the streptomycin. Thus a fourfold dilution of broth increased the end-point dilution of samples approximately fifty-fold, growth remaining satisfactory and easily detectable in such a weak medium. This increase in the sensitivity of the test was an advantage in the assay of low titre samples. A series of results for a sample of crude streptomycin assayed on different days in nutrient broth of $\mathrm{pH} \mathbf{7 \cdot 0}$ are given in Table 3 . The results for undiluted broth are each the mean of about 30, while those for the weaker medium are each the mean of about four results.

\section{Table 3. Variation of end-point dilution of a crude} streptomycin sample with dilution of test broth

Showing dilution of the sample required to produce end-point growth in each of six replicate tests using two strengths of nutrient broth.

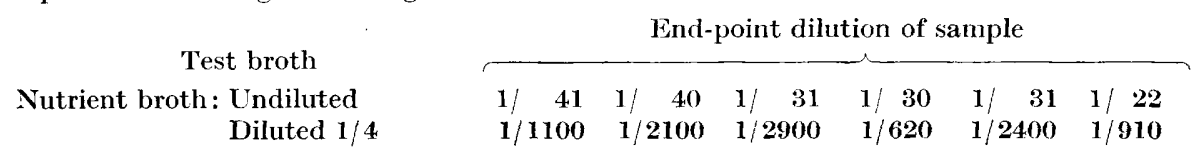

Temperature of incubation. During the first few weeks of streptomycin assay when tests were incubated at 37 and not $28^{\circ}$ (see Geiger et al., 1946) it was noticed that the growth of Esch. coli was irregular at the inhibition end of the test. Shaking the tubes vigorously after inoculation diminished the number of tubes growing unevenly, and incubation at $28^{\circ}$ was much more satisfactory than at $37^{\circ}$. This latter point was proved by counting the number of tubes each day where Esch. coli had multiplied freely in dilutions of antibiotic less than those showing inhibition both in tests incubated at 37 and at $28^{\circ}$. A statistical analysis of these 'odd tube' counts was made using Poisson's series. For 1642 tests the mean number of tubes out of order at $37^{\circ}$ was $11 \cdot 16 \%$ and for 1880 tests at $28^{\circ}$ it was $3.03 \%$. The difference between these two means is highly significant $(P=0.0078)$.

Quantity of inoculum. Some of the early assays were carried out in modified penicillin assay broth (Pope \& Stevens, 1946) and in general the inoculum used for tests in papain-digest medium was $0 \cdot 2 \mathrm{ml}$. of a $10^{-6}$ dilution of broth culture. Variation of this volume gave results which suggested that the end-point dilution is roughly inversely proportional to the quantity of inoculum $/ \mathrm{ml}$. of test broth (see Table 4) and indicated that care must be taken to use a constant inoculum.

Table 4. Variation of end-point dilution with size of inoculum

The table relates the dilution of sample required for end-point growth, with volume of inoculum $\left(10^{-6}\right.$ dilution of $17 \mathrm{hr}$. broth culture of Esch. coli) at two concentrations of medium. The broth used was a papain-digest of beef muscle, pH 9.0.

$\begin{array}{ccc}\text { Test broth dilution } & \begin{array}{c}\text { Volume of inoculum } \\ \text { (ml.) }\end{array} & \text { End-point dilution } \\ 1 / 4 & 0 \cdot 2 & 1 / 257 \\ & 0 \cdot 4 & 1 / 143 \\ 1 / 16 & 0 \cdot 2 & 1 / 47000 \\ & 0 \cdot 8 & 1 / 8200\end{array}$




\section{The effect on assay values of different $\mathrm{pH}$ values of the test broth and of the addition of oxidizing and reducing agents}

The effect of $\mathrm{pH}$. Reference has already been made to published work on the effect of various agents added to the test broth on the streptomycin assay values. The discovery that vigorous shaking often gave more consistent results suggested that oxidizing and reducing agents might have significant effects on the action of streptomycin in the assay. As some of these agents also had an effect on the $\mathrm{pH}$ of the test broth the effect of variation of the $\mathrm{pH}$ on the endpoint concentration of streptomycin base was first investigated (see Table $\mathbf{5}$ ). It was found during this experiment that the $\mathrm{pH}$ of the broth used for the routine tests fell from pH $\boldsymbol{\gamma} \cdot 6$ to $\boldsymbol{7} \cdot 4$ on re-autoclaving. The variation in activity from $\mathrm{pH} 7 \cdot 2$ to $7 \cdot 4$ and from $\mathrm{pH} 7 \cdot 4$ to $7 \cdot 6$ was rather more than $20 \%$. This means that for each decrease of $0 \cdot 1$ unit of $\mathrm{pH}$ between $7 \cdot 6$ and $7 \cdot 2$ the streptomycin activity was decreased by $c .10 \%$. Wollinsky \& Steenken (1946) showed that the greatest diminution in activity occurred between $\mathrm{pH} 6 \cdot 6$ and $5 \cdot 9$.

Table 5. Variation of amount of streptomycin base at the end-point in relation to the $\mathrm{pH}$ of the test broth

\begin{tabular}{|c|c|c|c|}
\hline Experiment & $\mathrm{pH}$ of broth & $\begin{array}{l}\text { Average weight } \\
\text { of streptomycin } \\
\text { base at } \\
\text { end-point } \\
(\mu \mathrm{g} .)\end{array}$ & $\begin{array}{c}\text { Percentage variation } \\
\text { in activity }\end{array}$ \\
\hline A (16 determinations) & $7 \cdot 2$ & $2 \cdot 73$ & -20 to +24 \\
\hline B (16 determinations) & $7 \cdot 4$ & $2 \cdot 19$ & $\{-2000+20$ \\
\hline C ( 7 determinations) & $7 \cdot 6$ & $1 \cdot 71$ & \}-22 to +28 \\
\hline
\end{tabular}

The effect of certain oxidizing and reducing agents. In the determination of the effect of oxidizing or reducing agents a concentration of substance was used such that growth of the organism in its presence was comparable to that in broth alone, and in all experiments controls of growth were included. The limit of growth was measured as the greatest dilution at which opalescence was apparent in a ten-fold dilution series. The concentration of the material was also varied by tenfold, starting at a $1 / 5$ or $1 / 10$ dilution. Diverse substances were chosen so that no common chemical group would be responsible for the oxidation or reduction. The concentration of each of the agents which inhibited growth in broth alone, inhibited growth in the presence of streptomycin, with the exception of hydrogen peroxide (' 20 vol.' solution) however, which inhibited growth. in broth alone at a dilution of $10^{-3}$ but not in the presence of streptomycin.

The results in Table 6 are expressed as the percentage change in the number of $\mu \mathrm{g}$. streptomycin base estimated as being present at the end-point of the experimental test as compared with those in the control routine test.

The changes in streptomycin activity observed when using the reducing agents was partly due to change in $\mathrm{pH}$. Hydroxylamine hydrochloride and 
thiolacetic acid show very little effect on the streptomycin titre (cf. Cavallito, 1946). The action of sodium dithionite was different, only about a third of the total effect being due to $\mathrm{pH}$ change.

Table 6. Variation in the activity of streptomycin in the presence of certain oxidizing and reducing agents at the maximum concentration having no effect on the growoth of Esch. coli

\begin{tabular}{|c|c|c|c|c|}
\hline Reagent & $\begin{array}{l}\text { Final dilution } \\
\text { in test broth }\end{array}$ & $\begin{array}{l}\text { Change in } \\
\text { pH of broth }\end{array}$ & $\begin{array}{l}\text { Crude } \\
\text { filtrates }\end{array}$ & $\begin{array}{c}\text { Purified } \\
\text { streptomycin }\end{array}$ \\
\hline
\end{tabular}

Oxidizing agents :

$\begin{array}{lcccc}\text { Iodine } & 10^{-4} & \text { None } & +3 \cdot 8 & -0 \cdot 6 \\ \text { K permanganate } & 10^{-4} & \text { None } & +15 \cdot 3 & +16 \cdot 0 \\ \text { Hydrogen peroxide (20 vol.) } & 10^{-4} & \text { None } & +4 \cdot 5 & +3 \cdot 6 \\ \text { Reducing agents: } & & & & \\ \begin{array}{l}\text { Sodium dithionite } \\ \text { ('hydrosulphite') }\end{array} & 10^{-3} & -0 \cdot 2 & +75 & +72 \cdot 4 \\ \begin{array}{l}\text { Hydroxylamine } \mathrm{HCl} \\ \text { Thiolacetic acid }\end{array} & \mathbf{2 \times 1 0 ^ { - 5 }} & -0 \cdot 1 & +19 \cdot 6 & +18 \cdot 5 \\ & 10^{-4} & -0 \cdot 1 & +22 & +12\end{array}$

We wish to thank Mr L. V. Bennett, Miss E. Howard, Miss G. Puddefoot and the technical assistants who made this assay work possible; we are indebted to $\mathrm{Mr}$ J. G. C. Campbell for the formula and preparation of the medium.

\section{REFERENCES}

Aвraham, E. P. \& Duthie, E. S. (1946). Effect of pH of the medium on activity of streptomycin and penicillin. Lancet, i, 455 .

Ainsworth, G. C., Brown, A. M., Marsden, P.S. S. F., Smith, P. A. \& Spilsbury, J. F. (1947). A method for the large-scale production of streptomycin by surface culture. J. gen. Microbiol. $1,335$.

Bondi, A., Dietz, C. C. \& Spaulding, E. H. (1946). Interference with the antibacterial action of streptomycin by reducing agents. Science, 103, 399.

Cavallito, C. J. (1946). Relationship of thiol structures to reaction with antibiotics. J. biol. chem. 164, 29.

Denkelwater, R., Cook, M. A. \& Tisiller, M. (1945). The effect of cysteine on streptomycin \& streptothricin. Science, 102, 12.

Donovick, R. \& RAKE, G. (1946). Influence of certain substances on activity of streptomycin in vitro. 1. Modifications in test medium. Proc. Soc. exp. Biol., N.Y., 61, 224.

Donovick, R., Rake, G. \& Fried, J. (1946). The influence of certain substances on the antibiotic activity of streptomycin in vitro. 2. The action of some carbonyl reagents on streptomycin. J. biol. Chem. 164, 173.

Geiger, W. B., Green, S. R. \& Waksman, S. A. (1946). The inactivation of streptomycin and its practical applications. Proc. Soc. exp. Biol., N.Y., 61, 187-92.

Hoвby, G. L., Lenert, F. \& Hyman, B. (1946). Factors influencing the action of streptomycin in vitro. J. Bact. 51, 606.

Madigan, D. G., Swift, P. N. \& Brownlee, G. (1947). Clinical \& pharmacological aspects of the toxicity of streptomycin. Lancet, i, 9 . 
Molitor, H., Graessle, O. E., Kuna, S., Mushett, C. W. \& Silber, R. H. (1946). Some toxiological and pharmacological properties of streptomycin. J. Pharmacol. 86, 151.

Pope, C. G. \& Stevens, M. F. (1946). The assay of penicillin by the dilution method. Bull. Hlth Org. L.o.N. 12, 274.

Van Dolah, R. W. \& Christenson, G. L. (1947). Chemical inactivation of streptomycin. Arch. Biochem. 12, 7.

WaKsman, S. (1945). Standardization of streptomycin. Science, 102, 40.

Waksman, S. \& Schatz, A. (1945). Streptomycin-origin, nature and properties. J. Amer. pharm. Ass. 34, 273.

Wolinsky, E. \& Steenken, W. (1946). Streptomycin and penicillin resistant staphylococci; influence of $\mathrm{pH}$, and body fluids on streptomycin action. Proc. Soc. exp. Biol., N.Y., 62, 162.

Woodthorpe, T. J. \& Ireland, D. M. (1947). A method for extracting and purifying streptomycin suitable for large-scale production. J. gen. Microbiol. 1, 334.

(Received 21 February 1947) 